\title{
Flour quality and kernel hardness connection in winter wheat
}

\author{
B. P. Szabó \\ e-mail: szpb@mk.u-szeged.hu
}

A. Véha

e-mail: veha@mk.u-szeged.hu

\author{
E. Gyimes
}

e-mail: gyimes@mk.u-szeged.hu

Zs. H. Horváth

e-mail: horvatzs@mk.u-szeged.hu

University of Szeged, Faculty of Engineering, H-6725 Moszkvai krt. 5-7., Szeged, Hungary

\begin{abstract}
Kernel hardness is controlled by friabilin protein and it depends on the relation between protein matrix and starch granules. Friabilin is present in high concentration in soft grain varieties and in low concentration in hard grain varieties. The high gluten, hard wheat flour generally contains about $12.0-13.0 \%$ crude protein under Mid-European conditions. The relationship between wheat protein content and kernel texture is usually positive and kernel texture influences the power consumption during milling. Hard-textured wheat grains require more grinding energy than soft-textured grains.

The aim of our research was to determine the possible relationship between kernel hardness and various other parameters of the flour (dough visco-elastic characteristics, wet gluten, water absorption, flour recovery, alveograph). We used Perten SKCS 4100 to determine the kernel hardness, while the Perten 3303 mill was used to establish Particle Size Index (PSI). Registered and widely used Hungarian wheat varieties (7 of HRWW and 4 of SRWW) were applied in the study. Twin correlations were used to determine the relationship among the various traits.

According to the results, there is a very strong correlation between milling energy and kernel hardness $(r=0.99)$. The correlation between
\end{abstract}

Keywords and phrases: wheat kernel, flour parameters, SKCS 4100 
hardness index and the examined flour parameters was also significant $(\mathrm{r}=0.81-0.87)$. We found strong correlation between the milling energy and water absorption $(\mathrm{r}=0.88)$ of flour. The associations found in this study will help the better understanding of the technological aspects concerning wheat grain and flour quality.

\section{Introduction}

Kernel hardness has a profound effect on the resulting flour's baking properties. The flour which is made from hard wheat has a medium to high protein content and contains stronger gluten-forming proteins than the flour which is made from soft wheat.

Kernel texture is very strongly heritable in wheat. Friabilin protein determines kernel hardness. When the amount of friabilin is high, kernel hardness is low and when the amount of friabilin is low kernel hardness is high. We can classify kernel hardness in these two groups (Greffeuille et al., 2006). Hardness in wheat is largely controlled by genetic factors, but it can also be affected by the environment and other factors such as lipid, moisture, and pentosan content. Friabilin, a marker protein for grain softness, consists of two proteins, puroindoline $\mathrm{a}$ and $\mathrm{b}$ (Martin et al., 2006). Lipid-binding proteins puroindolines a (PINA) and b (PINB) have been identified as responsible for determining differences between hard- and soft-textured wheat (Gyimes, 2004; Gyimes et al., 2001).

The high gluten, hard wheat flour generally contains about $12.0-13.0 \%$ crude protein under Mid-European conditions. The relationship between wheat protein content and kernel texture is usually positive and kernel texture influences power consumption during milling. Hard-textured wheat grains require more grinding energy than soft-textured grains (Békési, 2001).

Good mill and baker quality wheat belong to the hard grain type. Both the milling industry and the baking industry (making of bread) prefer this type. The hard endosperm composition is in close relationship with the large flour yield (greater ratio of the valuable fraction), the flour's greater water consumption, the volume of the bread, the bread's quality parameters (e.g. inner height), and the protein content (Véha, 1999).

For the determination and measuring of the endosperm structure, kernel hardness indicators were made, which measure the power needed to snap a seed. With this method, they determine a factor: Hardness Index (HI), which is one of the bases of mill crop's acceptance qualification. 


\section{Objectives}

Our aim is to determine kernel hardness. In our investigation, we have used the Perten SKCS 4100, the Perten 3303 mill. We used Hungarian samples. Registered and widely used Hungarian wheat varieties ( 7 of HRWW and 4 of SRWW) were applied in the study, which were assigned code numbers.

\section{Measurement methods}

The Perten SKCS 4100 instrument (Figure 1) is one of the well-known machines which examine kernel hardness. This device measures kernel texture by crushing the kernels and recording the force required to crush the kernel. This machine reports the average force required to crush 300 kernels, in terms of a hardness index (HI). The SKCS-4100 can complete a test in about 3 minutes and it simultaneously reports mean and standard deviation data for diameter, kernel weight, moisture content, and the HI. (Szabó, 2006).

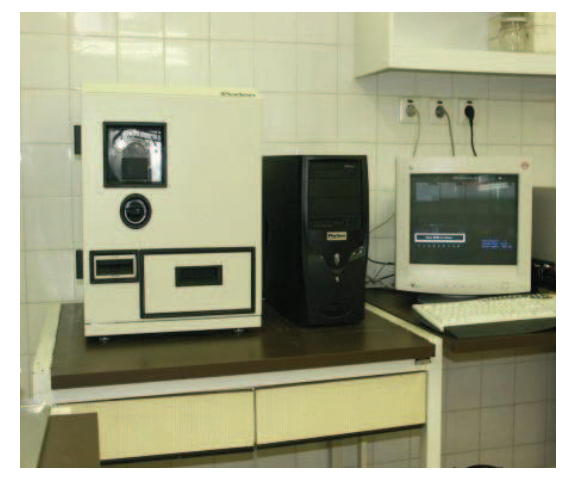

Figure 1: Perten SKCS 4100 instrument

We used Perten 3303 mill (Figure 2) to determine the Particle Size Index (PSI). This involves grinding a sample, and sieving a weighed amount through a standard screen for a standard time. Particle size index (PSI) helps us to determine the texture of a wheat kernel. We determine the specific grinding energy demand $\left(\mathrm{e}_{\mathrm{f}}\right)$. All measurements were repeated 3 times.

We measured the dough visco-elastic characteristics, water absorption, wet gluten, and alveograph. Milling test: we used Brabender ( $)$ Quadrumat ( Senior (Brabender GmbH \& Co. KG, Duisburg, Germany) laboratory mill to 
check the milling properties of different types of grain and determining the flour yield (FL) of the wheat sample.

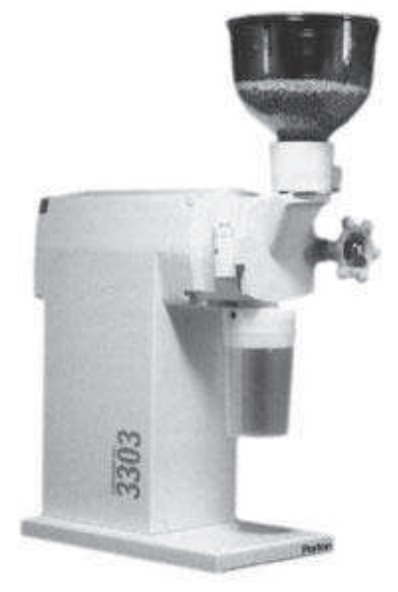

Figure 2: Perten 3303 laboratory mill

Gluten index: gluten index (GI) was examined by Glutomatic 2200 (Perten Instruments AB Huddinge, Sweden). Dry gluten content was measured after drying with Glutork 2020 (Perten Instruments AB Huddinge, Sweden) automatic gluten dryer. Farinograph test: we used the Brabender@farinograph (Brabender GmbH \& Co. KG, Duisburg, Germany). The farinograph determines dough and gluten properties of a flour sample by measuring the resistance of dough against the mixing action of blades.

Alveograph characteristics: Chopin Alveorgraph NG (CHOPIN Technologies, Villeneuve-la-Garenne Cedex, France). The alveograph test was performed according to the EU standards. The results include P Value, L Value, $\mathrm{P} / \mathrm{L}$ Value, and W Value.

\section{Results}

The SKCS 4100 compartmentalizes the results in two groups: under 50 is soft grain (the hardness index was between 27 and 36) and above 50 is hard grain (the hardness index was between 57 and 81).

We use twin correlation to determine the relationship between the results. Table 3 shows the result of the analysis. 
Table 1: Flour parameters

\begin{tabular}{|c|c|c|c|c|c|c|c|c|}
\hline \multirow{2}{*}{$\begin{array}{l}\text { Sample } \\
\text { code }\end{array}$} & \multirow{2}{*}{$\begin{array}{c}\text { Moisture } \\
(\%)\end{array}$} & \multirow{2}{*}{$\begin{array}{c}\text { Milling } \\
(\%)\end{array}$} & \multirow{2}{*}{$\begin{array}{c}\text { Water } \\
\text { absorbent }\end{array}$} & \multirow{2}{*}{$\begin{array}{c}\text { Wet } \\
\text { gluten } \\
(\%)\end{array}$} & \multicolumn{4}{|c|}{ Alveograph } \\
\hline & & & & & $\mathrm{P}$ & $\mathrm{L}$ & $\mathrm{P} / \mathrm{L}$ & W \\
\hline II. & 13.27 & 71.88 & 54.8 & 21.58 & 42.40 & 65.5 & 0.65 & 102.06 \\
\hline III. & 13.86 & 71.79 & 57.3 & 27.48 & 63.49 & 93.8 & 0.68 & 204.54 \\
\hline VI. & 14.01 & 74.01 & 54.0 & 16.85 & 45.72 & 51.5 & 0.89 & 103.99 \\
\hline IX. & 14.00 & 68.33 & 56.6 & 25.30 & 49.99 & 67.3 & 0.75 & 123.80 \\
\hline IV. & 13.90 & 72.89 & 60.9 & 28.13 & 88.25 & 70.0 & 1.26 & 251.35 \\
\hline VII. & 13.85 & 71.28 & 61.4 & 22.88 & 105.5 & 43.0 & 2.45 & 195.84 \\
\hline VIII. & 13.58 & 70.16 & 63.2 & 33.68 & 87.95 & 75.5 & 1.14 & 226.64 \\
\hline X. & 13.37 & 70.96 & 67.9 & 31.70 & 93.18 & 59.9 & 1.56 & 178.48 \\
\hline XI. & 13.15 & 67.94 & 66.8 & 35.60 & 100.3 & 47.0 & 2.16 & 189.91 \\
\hline XII. & 12.82 & 70.46 & 63.0 & 29.68 & 103.9 & 61.5 & 1.69 & 252.19 \\
\hline XIII. & 12.92 & 69.66 & 56.9 & 31.08 & 54.85 & 66.0 & 0.83 & 148.09 \\
\hline
\end{tabular}

Table 2: Results of SKCS 4100 and Perten 3303 mill

\begin{tabular}{lcc}
\hline Samples & $\begin{array}{c}\text { Perten SKCS } 4100 \\
(\text { HI } \%)\end{array}$ & $\begin{array}{c}\text { Perten } 3303 \text { mill } \\
\left(e_{\mathrm{f}} \mathrm{mWh} / \mathrm{cm}^{2}\right)\end{array}$ \\
\hline II. & 27 & 0.235 \\
III. & 36 & 0.245 \\
VI. & 20 & 0.215 \\
IX. & 29 & 0.255 \\
IV. & 61 & 0.440 \\
VII. & 57 & 0.435 \\
VIII. & 67 & 0.465 \\
X. & 81 & 0.555 \\
XI. & 81 & 0.545 \\
XII. & 81 & 0.535 \\
XIII. & 68 & 0.470 \\
\hline
\end{tabular}

Table 2 shows also the Perten-HI and grinding energy values in the tests. The SKCS 4100 compartmentalizes the results in two groups. Under 50, the entries belong to the Soft Wheat category, while entries above values of 50 are considered as a Hard Wheat category. The average HI was 55.2 with values between $20(\min )$ and $81(\max )$. 
Table 3: Correlation matrix for the technological traits and grinding energy of wheat entries in Szeged, Hungary

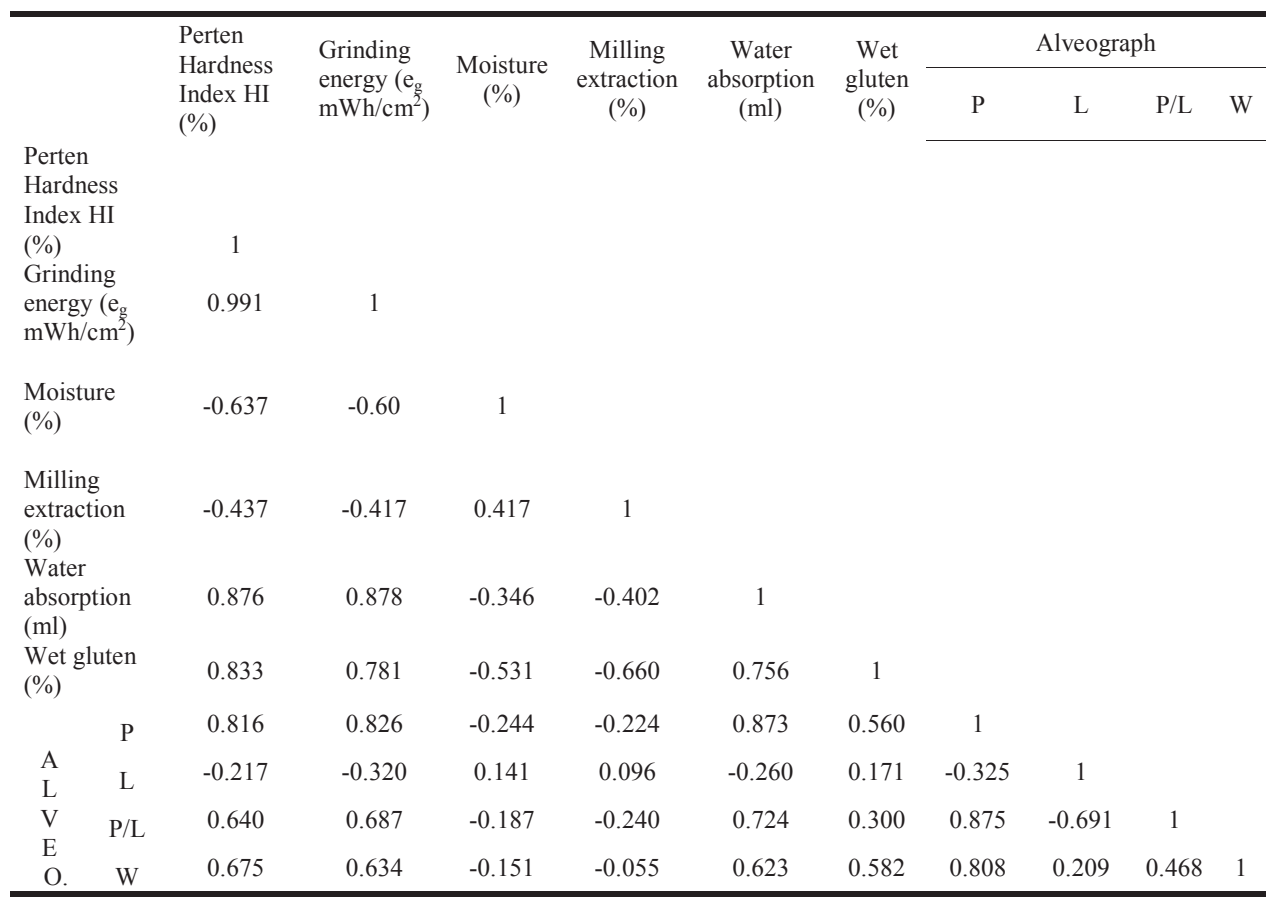

According to the results, there is a very strong correlation between milling energy and kernel hardness $(\mathrm{r}=0.99)$ (Figure 3). The correlation between hardness index and the examined flour parameters was also significant $(\mathrm{r}=$ $0.81-0.87)$. We have found strong correlation between milling energy and water absorption $(\mathrm{r}=0.88)$ of the flour. For example: hardness index wet gluten $\mathrm{r}=0.83$; hardness index - water absorption $\mathrm{r}=0.88$ (Figure 4), hardness index $-\mathrm{P}$ value of alveograph $\mathrm{r}=0.82$. There is a correlation between the ef and water absorption $\mathrm{r}=0.88$. We have found correlation between water absorption and $\mathrm{P}$ value of alveograph, $\mathrm{r}=0.87$.

Sample set "B" showed a very close correlation with the Hardness Index, measured by SKCS 4100, the water absorbance capacity of the flour (Figure 4 ), made out of the crops, and obtained an acceptable correlation with the flour's wet gluten content, and the alveograph deformation work as well. 


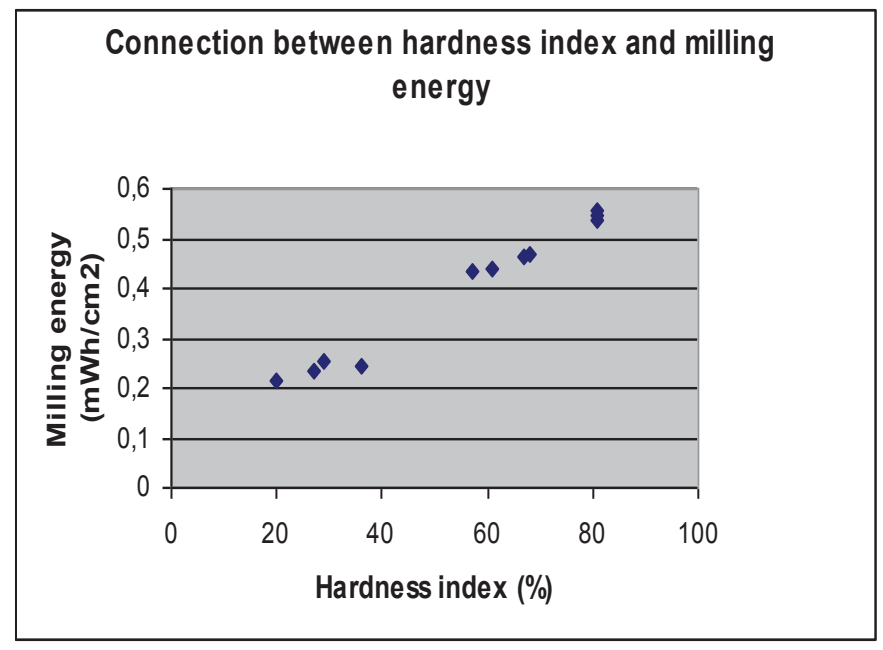

Figure 3: HI and milling energy (ef) connection

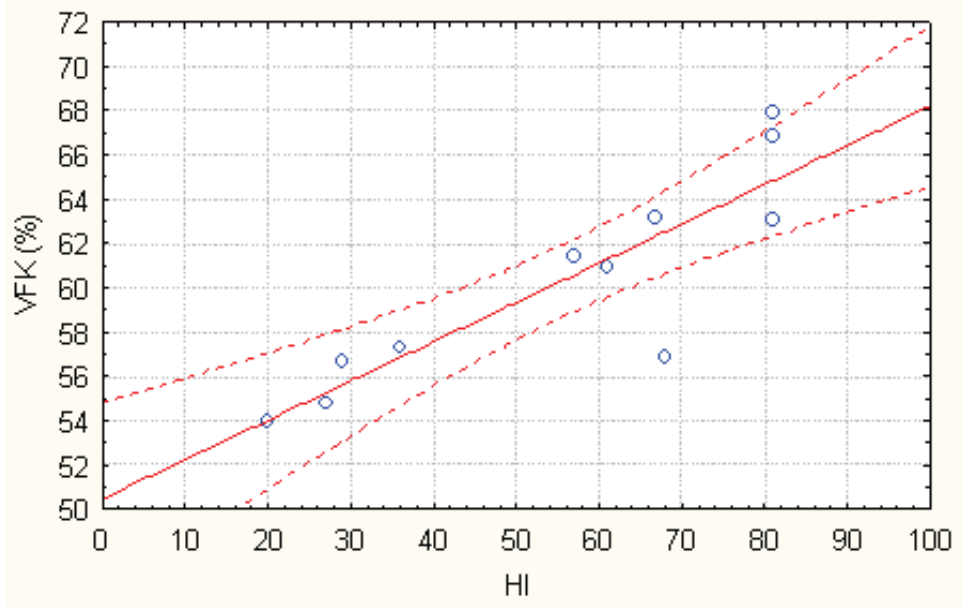

Figure 4: Connection between water absorbance capacity and Hardness Index

The associations found in this study will help to better understand the technological aspects of wheat grain and flour quality as well as provide useful information to breeders to develop new, high-quality hard and soft wheat varieties. 


\section{References}

[1] F. Békési, A búza endospermium szerkezetének szerepe néhány minőségi búzát termelő országban. (The role of the wheat endosperm structure in some quality-wheat-producing countries). In: Z. Bedo. (ed.), A jó minőségü, keményszemü búza nemesitése és termesztése. (Breeding and cultivation of good-quality and hard-kernel wheat). (2001) $25-34$.

[2] V. G. Abecassis, J. M. Rousset, A. O. Faye, L. Bar, C. 'Helgouac'h, V. Lullien-Pellerin, Grain characterization and milling behaviour of nearisogenic lines differing by hardness. Theor. and Applied Genetics, 114. (2006) 1-12.

[3] E. Gyimes, M. Neményi, A. Véha, Reológia és szemkeménység összefüggése őszi búzáknál. (Rheology and hardness relationship in autumn wheat). In: Ötven éves az Acta Agronomica Hungarica Martonvásár. (2002) 117-124.

[4] E. Gyimes, Összefüggés-vizsgálatok búzafajták szemtermésének agrofizikai tulajdonságai között. (Investigations of relationships among the agro-physical features of wheat (Triticum aestivum) kernel varieties), Doktori (PhD) értekezés, Mosonmagyaróvár, PhD thesis [in Hungarian]. (2004) 11-42.

[5] J. M. Martin, F. D. Meyer, E. D. Smidansky, H. Wanjugi, A. E. Blechl, M. J. Giroux, Complementation of the pina (null) allele with the wild type Pina sequence restores a soft phenotype in transgenic wheat. Theor. and Applied Genetics, 113. (2006) 1563-1570.

[6] P. B. Szabó, A búza szemkeménységének a meghatározása a Lloyd 1000 $\mathrm{R}$ állományvizsgáló segítségével. (Measuring wheat kernel hardness by Lloyd 1000 R testing machine), VII. Nemzetközi Élelmiszertudományi Konferencia (VII. International Food Sciences Conference), Szeged. (2006) 64-65.

[7] A. Véha, E. Gyimes, Szemkeménység vizsgáló módszerek összehasonlítása őszi búzák esetében. (Comparison of hardnesstesting methods for autumn wheat). http://www.date.hu/kiadvany /tessedik/4/veha.pdf. (1999). 